From the Department of Child Health, Port Moresby

General Hospital, Papua New Guinea

\title{
The Role and Training of Hospital Paediatric Nurses in Papua New Guinea.
}

\author{
by
}

JOHN BIDDULPH.

\begin{abstract}
Demands for health services are increasing in all countries of the world.

Both affluent and less affluent countries are starting to realise to the importance of nurse practitioners to enable comprehensive health services to be made available to more people at cheaper cost.

The training programme for hospital paediatric nurses in Papua New Guinea has been designed to allow them to carry out effectively their future role of taking responsibility for the screening, diagnosis and initial treatment of sick children pending the availability of a doctor.

The nurses receive practical on the job training by rotating through specific areas during the one year post basic course in paediatric nursing. The areas are acute paediatric ward, gastroenteritis ward, special care nursery, paediatric outpatients, nutrition rehabilitation unit and $\mathrm{MCH}$ clinics.

The nurses learn to diagnose the common acute paediatric illnesses. They learn standardised management regimens for each of these common childhood illnesses.

They also learn how to carry out the practical procedures required to allow them to diagnose and treat these illnesses, and become skilled in doing such procedures as lumbar punctures and intravenous rehydration.
\end{abstract}

Received 15th July, 1974. 
Health service demands are increasing in all countries of the world. In America, nurse practitioners and paediatric nurses are being trained in several centres to provide many of the services previously done by doctors. They provide a cheaper service, allow a wider coverage of the population and perform their tasks as well as doctors.

The utillisation of nurse practitioners alliows fullest advantage to be taken of scarce and expensive high level manpower. It thus enables health services to be available to more people at much cheaper cost (Silver, 1968; Silver and Hecker, 1970; Salder et al., 1972).

There is clearly a much greater need for nurse practitioners in developing countries such as Papua New Guinea than in developed countries such as America. Inideed, most nurses in Papua New Guinea now function as doctors of first contact. It is essential, then, that their training provides them with adequate sk:llis for screening, diragnosis and treatment of patilents.

A 12 months' post-basic course in paediatric nursing recognised by the Nunsing Council of Papua New Guinea has been establisheid at Port Moresby. After satisfactory completion of the course the nurses are assigned to paedliatric wards in the regional and district hospitals of the country.

\section{The need for paediatric nurses}

One third of the population of Papua New Guinea are children under ten years of age, yet $40 \%$ of hospital admissions and $60 \%$ of hospital deaths occur in this age group. Clearly, children form bolth a large and a vulnerable group.

Infections are responsible for $90 \%$ of the admissions of chilldren to hospital. At least one third of these children are also malnourished, so that the main cause of the high morbidity and mortality among young children is infection and malrutrition, each adversely interacting on the other.

Four infections - lower respiratory infection, diarrhoea, malaria and meningitis - account for $45 \%$ of all paediatric admissions to hospital and $55 \%$ of all paediatric deaths in hospital.

The majority of paediatric admissions and deaths are, therefore, caused by only a few acute diseases. Diseases which, if recognised early, can be readily treated and the child is able to return to full function. Most children suffer from, and die from, acute infections which can be readily recognised and which are capable of being successfully managed by standardised treatment regimens.

Over one third of hospital paediatric deaths in Papua New Guinea occur within 24 hours of the child's 


\section{Give Fast}

$20 \mathrm{ml}$. per $\mathrm{kg}$.

\section{Then Each Hour}

$25 \mathrm{ml}$. if weight under $5 \mathrm{~kg}$.

$50 \mathrm{ml}$. if weight $5-9 \mathrm{~kg}$.

$75 \mathrm{ml}$. if weight $10-14 \mathrm{~kg}$.

$100 \mathrm{ml}$. if weight $15 \mathrm{~kg}$. or more.

Repeat 20 ml. per kg. FAST if child continues ito look dehydrated.

Encourage Breast Feeding and Oral Fluids

\section{Initial Treatment of Meningitis}

Diagnosis - Lumbar puncture shows clouảy C.S.F.

1. Put up Glucose-Saline intravenous drip.

$10 \mathrm{mll}$. per hour if weight under $5 \mathrm{~kg}$.

$25 \mathrm{ml}$. per hour if weight $5-14 \mathrm{~kg}$. $50 \mathrm{ml}$. per hour if weight $15 \mathrm{~kg}$. or more.

2. I.V. Cryst. Penicillin $1,000,000$ U. every three hours.

3. I.V. Sulphadimidine $50 \mathrm{mg}$. per kg. (max. 1.5 g.) every six hours.

4. I.V. Chloramphenicol $25 \mathrm{mg}$. per kg. (max. $500 \mathrm{mg}$.) every six hours.

5. I.M. Chloroquine $0.1 \mathrm{ml}$. per $\mathrm{kg}$. stat.

6. Phenobarbital $15 \mathrm{mg}$. every eight hours if weighit under $10 \mathrm{~kg}$. 30 mg. every eight hours if weight $10 \mathrm{~kg}$. or more.
7. I.V. Diazepam (Vailium) $0.1 \mathrm{ml}$ per kg. (max. 2 ml.) if child convulses or Paraldehyde $0.1 \mathrm{ml}$. per $\mathrm{kg}$. if Dilazepam (Vallium) not avauilable.

Particular attention is paid in the specijal care nursery to teach the nurses how to take care of low birth weight babies, especially the practical aspects of feodling and the importance of maintaining the mather's lactation.

Large numbers of children atitend the paediatric outpatients each day, and the nurses are taught how to screan the sick from the not sick chlidren.

Over $80 \%$ of new outpatient attendens have either a respiratory infection, a skin imfection or diarrhoea. Serious ilinesses apart from lower respiratory imfection and diarrhoea account for less than $3 \%$ of new attenders. So among the paedliatric outpatient population ithere is a in mited disease spectrum in which diagnosis is readilly apparent to those adiequatelly tralined in over $90 \%$ of cases. Management allong standardised lines is allso appropriate for $95 \%$ of cases. Thus it is adequately trained nurses, and not doctors, that are required to screen, diagnose and treat the chilldren that attend the outpaltient department.

The nurses learn how to make up various milk food that children may require. They learn the importance 
of food and how to ensure and maintain adequate nutrition for the sick chill.

The nurses allso spend time in the Nutritilon Rehabilititation Unit. Here they learn the importance of social factors in the causation of malnutrition, and participate in an active educational programme of teaching families better nutrition.

Although the hospital paediatric nurses are mainly concerned with sick children, it is inecessary for them to be knowledgeable on the preventive and educational aspects of child health. They learn to utillise a sick chill'd's time in hosplital for necessary preventive and educational work with the family. The child's immunisation status is checked whille he is in hospital, and deficiencies remedied before he is dilischarged home. Advice on child care and family planning may be needed and the nurse must be able to provide this. Also, adequate follow up of the child, after hils discharge from hospital, requires good liaison between hospital sitaff and the community health staff. The hospital nurse must know what community health facilities are available to provide ongoing care for the chilld.

The paediatric nurses become familiar with the working and problems of community paedliatricas by spending one month attached to M.C.H. Clinics. During this time they are actively involved in antenatal clinics, young chilld clinics, immunisations, school health, diental reaith, family plianning, health education, home visiting, pre-school activities, and social welfare.

The training given to the paediatric nurses is essentiailly practical as it has been found that they learn best by doing. Most of the teaching takes place in the real life situation of the wands and outpatients. However, six hours per week are spent in the classroom on tutorials, discussion groups and individual projects, and a series of lectures are given on ward management and adminisistration.

\section{Conclusion}

The hospital paediatric nurses are trained for total care of the sick child. They are taught to diagnose the common childhood illnesses and to initiate specific treatment pending the arrival of a doctor. They free the doctor of much routine work and thus allow him to spend more time at those taslus that specifically require his expertise and knowledge.

The use of nurses especially trained for their role in diagnosis and treatment is essential if adequate paediatric services are to be provided. To delegate suitable responsibilities to specifically trained nurses is not a detrimental dilution of standards of medical care. An adequate number of well-trained and supervised nurses properly used, is of much better value than a few doctors desperately attempting the impossible. 


\section{REIERENCES}

1. SADLER, A.M, SADLEF, B.L. and BLISS, A.A. : The Physician's Assistant - To-day and Tomorrow (Yale University Press, 1972).
2. SILVER, H.K. : J. am. med. Ass. $204: 298$ (1968).

3. SILVER, H.K. and HECKER, J.A. : J. Med, Educ. 45 : 171 (1970). 